УДК 177.9

DOI https://doi.org/10.32837/apfs.v0i32.1021

В. В. Готинян-Журавльова

ORCID ID: https://orcid.org/ 0000-0003-0830-3893

доктор філософських наук, доиент,

професор кафедри філософії, професор кафедри культурологї

Одеського національного університету імені I. I. Мечникова

\title{
ВПЛИВ СОЦІОКУЛЬТУРНИХ ЗМІН У СУСПІЛЬСТВІ НА СИСТЕМУ ЦІННІСНИХ ОРІЄНТАЦІЙ УЧЕНОГО
}

\begin{abstract}
Постановка проблеми в загальному вигляді та її зв'язок із важливими науковими завданнями. Еталонне вимірювання отримало таке широке застосування завдяки простоті процедури вимірювання i об'єктивності, незалежності від суб'єкта, який проводить вимірювання, отриманих результатів. Науковці не припиняють повторювати, що результати, отримані саме завдяки еталонному вимірюванню, мають універсальний об'єктивний характер, тому ïx можна піддавати математичній обробці. Але слід підкреслити, що вимірювання, зокрема еталонне, методологічно пов'язане зі спостереженням, а саме ті вимірювання, які відбуваються за допомогою шкал вимірюваних приладів, i ті, в яких результат отримуємо завдяки зчитуванню показників зі шкали. Існує навіть думка, що будь-яке вимірювання фізичної величини, яке відбувається за допомогою вимірювального приладу зі шкалою, можна звести до вимірювання довжини. Так, Р.Б. Ліндсей зазначає, що «всі вимірювання можна звести до приписування певного числа збігу стрілки вимірюваного приладу і різки на його шкалі» $[1$, с. 465], бо вимірювана величина визначається відстанню від нульової позначки до положення, яке зайняла стрілка. А тут існує елемент спостереження, який вимагає від дослідника, уваги і зосередженості. Крім того, слід підкреслити, що результати будь-якого спостереження (навіть наукового, етапи якого ретельно продумуються) не є об'єктивними. У науці існує спеціальний термін «інтерсуб'єктивність», який указує на те, що вимірювання побудоване так, щоб звести до мінімуму елемент суб'єктивності, тобто вплив дослідника, його уваги, емоцій, настрою, системи цінностей, на результат спостереження, i будь-які інші дослідники, повторюючи це спостереження, могли отримати подібний результат. Однак цікаво б дослідити не лише вплив емоцій, настрою і системи цінностей, а й те, як впливають суспільні зміни на систему ціннісних орієнтацій ученого і на подальший розвиток науки.
\end{abstract}

Аналіз останніх досліджень і публікацій із теми. Серед філософів, методологів науки, які досліджували використання альтернативних видів вимірювання та їх застосування в науці, зокрема в науках суспільно-гуманітарного циклу, слід указати на К. Берку, Р. Ліндсея, О.П. Пунченка.
Аналізуючи основні концепції й уявлення щодо системи цінностей i ціннісних орієнтацій, ми спиралися на роботи відомих сучасних українських і закордонних учених (К. Левіна, І. Кона, Б.Ф. Скіннера, В.Г. Алексєєвої, В.С. Бліхара, В.В. Водзянської, А.І. Донцова, О.М. Єременка, Н.А. Журавльової, Е.В. Ільєнкова, В.В. Ільїна, 0.0. Ручки). Досліджуючи зміни, які відбувалися останнім часом у науці, ми спиралися на роботи Дж. Агассі та Б.І. Пружиніна.

Мета статті - проаналізувати вплив змін, які відбуваються в суспільстві, на зміну пріоритетів сучасної науки та систему ціннісних орієнтацій i роботу вченого.

Використання процедури шкалування змусило вчених і методологів науки (замість еталонного вимірювання) розділити вимірювання на фізичні i позафізичні. Як зазначає К. Берка, позафізичне вимірювання «концептуально й операційно пов'язане з людиною, тобто з такими їі суб'єктивними властивостями, як емоції, настанови, бажання тощо, інакше кажучи, з такими його властивостями, які не можна виміряти» [2, с. 28]. Саме вплив суб'єктивних властивостей дослідника на процес і результат вимірювання, на думку К. Берки, відрізняє більшість вимірювань, які відбуваються в точних науках, від вимірювань, які проводять дослідники в суспільно-гуманітарних науках, де сама процедура вимірювання вимагає створення шкал, педагогічних і психологічних тестів, анкет для опитування, які не можна створити однаковими, універсальним, такими, на які не буде впливати автор. Позафізичне вимірювання, як i еталонне, або фізичне (за класифікацією К. Берки), методологічно пов'язане 3 класифікацією i спостереженням. Воно також визнається методологами як певний вид класифікації. Має такі два основних елементи, як об'єкт вимірювання і результат вимірювання, але результат уже не $є$ тим об'єктивним числом, яким він є в еталонному вимірюванні. Вимірювальними приладами $€$ не лише шкали, а й «спостереження, анкета, бесіда» [2, с. 29]. Оскільки шкалами в позафізичному вимірюванні найчастіше $є$ не шкали вимірювальних приладів, а ті, які створюються дослідниками (номінальна, порядкова, інтервальна тощо), то 3 
цього випливає його залежність від суб'єктивних факторів, зокрема від мети, яку визначає автор.

На нашу думку, безеталонне вимірювання $є$ позафізичним. Так, якщо ми проаналізуємо вид безеталонного вимірювання, який засновано на порівнянні вимірюваного об'єкта з об'єктом, який обрано квазіеталоном вимірюваної величини (позначається такий вид безеталонного вимірювання як $\left.\mathrm{R}\left(\mathrm{m}_{1}, \mathrm{~m}_{2}\right)\right)$ [3], то тут сам вибір квазіеталонів безпосередньо залежить від дослідника, який його проводить. Квазіеталонів може бути декілька, як у прикладі з вимірюванням довжини Удава. Пригадаємо, що спочатку квазіеталоном для порівняння довжини були Папуга, Мавпочка і Слоненя. Чому саме ці звірятка, а не інші? Пригадаємо приклад із вимірюванням твердості мінералів за відомою шкалою Мооса. Шкала була запропонована німецьким мінералогом Фрідріхом Моосом у 1811 році і містила десять найбільш розповсюджених мінералів: тальк, гіпс, кальцит, флюорит, апатит, ортоклаз, кварц, топаз, корунд, алмаз. Але майже для всіх мінералів можна знайти аналоги зі схожою твердістю. Так, тальк можна замінити графітом, гіпс - слюдою, кальцит - золотом або сріблом, кварц - гранатом або турмаліном. Єдиним мінералом, якому важко знайти аналог, є алмаз. Близьким за твердістю до нього є ельбор, але природного аналога алмазу за твердістю не існує. Крім того, існують й інші методи вимірювання твердості, як-от методи Віккерса, Роквелла тощо. Процедура створення нормативно орієнтованих тестів теж безпосередньо залежить від автора, його вимогливості і скрупульозності, від глибини вивчення матеріалу тими, хто буде тестуватися.

Те ж стосується виду безеталонного вимірювання, заснованого на порівнянні вимірюваної ознаки, яка належить досліджуваному об'єкту, з ознакою, обраною як умовний квазіеталон. Цей вид безеталонного вимірювання позначається як $\mathrm{R}\left[(\mathrm{m} *) \mathrm{P}_{1}, \mathrm{P}_{2}\right]$ [3]. У процедурі цього виду вимірювання $€$ ознака-квазіеталон, яка обирається дослідником, може виявитися не зовсім вдалою і бути замінена іншою, а може бути використана як квазіеталон лише під час одного вимірювання. Вибір будь-якого квазіеталону безпосередньо залежить від дослідника, його можливостей, уважності, вибагливості, скрупульозності. Прикладами цього виду вимірювання були відомі шкали англійських адміралів Бофорта і Дугласа, які були настільки вдало складені, що їх використовують дотепер, додавши певні моменти та уточнивши їх. Оцінка вчителем якості знань учнів, їх, наприклад, усної відповіді, теж безпосередньо залежить від вимогливості вчителя, а інколи, на жаль, і від інших його суб'єктивних факторів (настрою, стану здоров’я, мотивації і зацікавленості в роботі).

Звернімося до виду безеталонного вимірювання, заснованого на зіставленні ознаки з вимірюва- ною річчю з метою з'ясувати, чи належить ознака вимірюваній речі, який позначається як $\mathrm{R}(\mathrm{P}, \mathrm{m})$ [3]. У цьому разі також певною мірою присутній елемент суб'єктивності і відчувається вплив дослідника на обрання цих ознак, які приписуються об'єкту вимірювання. Так, під час безпосереднього огляду пацієнта відбувається зіставлення опорних діагностичних ознак із симптомами пацієнта, в результаті чого лікар з' ясовує, чи саме ця хвороба наявна в пацієнта. Кожен із нас знає, що, окрім оцих, здавалось би, еталонних ознак хвороби, існує ще й компетентність лікаря, його уважність, стан його власного здоров'я, зацікавленість у лікуванні й одужанні пацієнта тощо.

Під час пандемії, локдаунів і карантинів у більшості людей, окрім страху за своє життя, страху втратити здоров'я, виник страх втратити роботу, 3'явилася невпевненість у «завтрашньому дні» $\mathrm{i}$ депресивний стан як наслідок цього. Тому дуже популярними стали тести, засновані на шкалі депресії Бека, які визначають ступінь депресії. Ця шкала запропонована А.Т. Беком та його колегами в 1961 році. Вона розроблена на основі клінічних спостережень автора, в результаті яких виявлено певний набір найбільш значущих симптомів депресії і найбільш характерних скарг від пацієнтів. Далі цей набір симптомів був співвіднесений із клінічним описом депресії. На основі цього розроблено тест, який складається із 21 категорії симптомів i скарг. Кожна категорія містить 4-5 тверджень, які відповідають симптомам депресії. Ці твердження розташовані за мірою збільшення симптоматики в загальний ступінь тяжкості захворювання. Якщо спочатку тестування відбувалося під наглядом лікаря чи психолога, то зараз процедура тестування спростилася і той, хто тестується, сам обирає твердження з переліку, які відповідають його стану. Тест визначає актуальний стан того, хто тестується, а тому безпосередньо залежить від емоційного настрою, емоційного стану того, хто тестується. Якщо людна чимось пригнічена, якщо саме сьогодні з нею щось трапилося, то навряд чи результати тесту будуть сприятливими. Велика ймовірність того, що буде визначено, наприклад, легку депресію. Отже, слід підкреслити важливість проходження цього тесту не самостійно, а саме під наглядом компетентного спеціаліста, який, крім тесту, оцінюватиме анамнестичні дані, показники інтелектуального розвитку, інші параметри.

Четвертий вид безеталонного вимірювання, що базується на комбінації ознак, якими вимірюється, описується, з яких інколи утворюється вимірювана річ і який позначається як $\mathrm{R}\left(\mathrm{P}_{1}, \mathrm{P}_{2}, \mathrm{P}_{3}, \ldots\right)$ [3], містить елементи суб'єктивізму. Так, у психології часто проводяться вимірювання особливості поведінки людини, певних відмінностей між людьми відповідно до тих чи інших властивостей поведінки, 
того чи іншого психічного стану. Тобто вимірювання є методом фіксації стану, поведінки об’єкта дослідження і змін цього стану як відповіді на експериментальний вплив на нього. Але наша поведінка залежить від безлічі суб'єктивних факторів, пов' язаних зі станом не лише нашого психологічного здоров'я, а й здоров'я загалом, з усіма умовами, які передували тестуванню. Як зазначалося раніше, в теорії суперечки існує так звана «хитрість артиста», яка має допомогти тому, хто її застосовує, зіпсувати настрій своєму супротивнику, чим змінити на свою користь перебіг суперечки. Чому? Тому що перемога в будь-який суперечці залежить від безлічі факторів: наявності аргументів, зв'язку аргументів із тезою, вмінь і знань із дедукції та індукції, кількості часу на відповіді на запитання, а також від нашого стану, настрою, бажання перемогти. «Хитрість артиста» полягає в тому, щоб сказати щось неприємне супротивнику (повідомити неприємну новину, негативно висловитися стосовно його роботи або родини, зробити «комплімент» про те, як він постарів, погладшав тощо, грубо образити, перейти на особистості), чим «збити» його переможний настрій.

Може скластися враження, що позафізичне i, відповідно, безеталонне вимірювання занадто залежать від суб'єктивних факторів, щоб бути методом пізнання. Як не намагаються методологи, однак позбутися суб'єктивізму в науці неможливо. Наука не є універсальним механізмом, який може функціонувати відокремлено від людей, учених, які створюють цю науку. А позбавити людину впливу емоцій, мети, ціннісних орієнтацій, які сформувалися в неї протягом її життя, неможливо. Існує вислів: хто володіє собою, той володіє світом. Але досі ми так і не дізналися, хто з людей може настільки оволодіти собою, настільки «вимкнути» емоції, систему цінностей, власних бажань, щоб оволодіти світом.

Звернімося до цікавої й актуальної роботи Б.I. Пружиніна [4], в якій є покликання на статтю про дослідження в галузі ракових пухлин на молекулярному рівні і яка була опублікована в науковому журналі "Nature". Зокрема, автори статті констатували, що з 53 перевірених у лабораторії публікацій, які містили результати дослідження за цією тематикою, 47 наводили результати, яких не вдалося отримати в інших лабораторіях. Результати лише 6 досліджень більш-менш вдалося відтворити. Наголосимо, що результати 47 досліджень, які були опубліковані у відомих наукових виданнях, не вдалося відтворити в інших лабораторіях. Пригадаємо, що однією з характеристик наукового знання, хочемо підкреслити, що саме наукового знання, є повторюваність результатів іншими дослідниками в інших лабораторіях. Чому ж тоді так відбувається? Про що йдеться? Що це? Халатна недбалість, через яку у відомі на- укові журнали потрапила неперевірена інформація, чи гонитва за грантами, публікаціями в «рейтингових журналах», що входять до популярних наукометричних баз і наявність саме яких, а не знання, талановитість, досвідченість, педантичність, чесність ученого визначають його рейтинг, чи фальсифікація результатів задля отримання певних переваг?

На жаль, така ситуація стала типовою для сучасної науки і була зовсім неприпустимою для вчених XIX століття. Так, на питання Наполеона III про те, чому він не отримує прибуток зі своїх відкриттів, Луї Пастер відповів, що вважає принизливим для французького вченого отримувати гроші за свої відкриття. Як відомо, Луї Пастер був одним із фундаторів мікробіології, творцем ідеї вакцинації, винахідником вакцин проти сибірської виразки, курячої холери, сказу. Перша приватна хімічна лабораторія, в якій проводили дослідження «за гроші», «за винагороду», відкрита Юстасом Лібігом і була більше винятком, ніж правилом.

Висловити припущення, яке потім не знайде підтвердження, поставити експеримент, результати якого потім не зможуть відтворити інші вчені, було неприпустимим для вченого того часу, бо могло вартувати йому наукового імені і наукової кар'єри. Дж. Агассі зазначає, що вимога абсолютної демонстративності в науці «змушувала визнавати вченого «винним у <...> помилці, якій немає пробачення» (покликаючись на сера Джона Гершеля), якщо він висловить припущення, яке може виявитися хибним» [5, с. 138-139]. Виникла ситуація, в якій краще було промовчати, ніж висловити припущення, яке потім могло виявитися хибним, або посилатися на результати експерименту, які потім не можна було б отримати в інших лабораторіях. Такі вимоги перетворювали життя вченого на пекло, але вони існували. Історії науки відомий випадок, коли на початку ХХ століття знаний французький фізик Рене Проспер Блондо повідомив про відкриття нових променів, зроблене в його лабораторії. Але в інших лабораторіях повторити цей експеримент не вдалося. Через це вчений втратив розум.

Які зміни відбулися в самій науці, що для вчених перестало бути значущим висловити майже бездоказове припущення, втратити контакт із передовою межею науки, не знати про новітні відкриття, не користуватися новітніми технологіями, стало не зовсім важливим, якщо раптом тебе стануть уважати "старомодним», несучасним і ти втратиш контакт із молодими поколіннями вчених? Усі ці питання бентежили вчених XX століття. Які зміни в системі ціннісних орієнтацій ученого відбулися за останні сто років?

По-перше, слід підкреслити, що зміни відбулися в самій науці і в суспільстві. У XIX-XX століттях розвивалася переважно «чиста» фундамен- 
тальна наука, яка займалася розробкою цілісної системи знань. А тому серед основних вимог до наукового знання були аргументованість, повторюваність, загальнозначущість знання. Наприкінці XX - на початку XIX століття на перший план виходять прикладні дослідження, які мають зовсім інші цілі і зовсім інші вимоги до отриманого знання. Як зазначав П.Л. Капіца ще в 1934 році, «у нас постійно плутають чисту науку з прикладною. Це природно і зрозуміло, але також є джерелом багатьох помилок. Різниця між прикладною науковою роботою і чистою науковою роботою в методах оцінки. Як будь-яку прикладну роботу можна безпосередньо оцінити за тими чи іншими конкретними результатами, які мають бути зрозумілими навіть не експерту, чисту наукову діяльність оцінити вкрай складно, до того ж ця оцінка доступна більш вузькому колу людей, які цікавляться цими питаннями» [цит. за 4, с. 7]. Точніше ці зміни не опишеш. У сучасній науці акцентовано на прикладних дослідженнях, оскільки вони локалізовані, стосуються вирішення конкретних завдань і мають практичне застосування, що буде приносити прибуток його авторам чи власникам.

Однією із суттєвих відмінностей прикладного і фундаментального досліджень є наявність у прикладних дослідженнях ще однієї фігури - замовника дослідження. Будь-яке сучасне грунтовне дослідження потребує сучасного обладнання, новітніх реактивів, закупки відповідних ліцензійних комп'ютерних програм, штату співробітників тощо. Фінансування відбувається зі сторони або держави, або замовника. Замовника, спонсора певного дослідження найчастіше цікавлять не фундаментальні знання як самоціль, а можливість реалізувати нові знання задля отримання певної вигоди (наприклад, отримати прибуток із виробництва вакцини, яка була створена вченими за його замовленням). Отримані знання він уважає своєю власністю, адже він профінансував процес їх отримання. А оскільки знання були не самоціллю, а засобом для отримання прибутку в подальшому, то замовник не має жодного наміру розповсюджувати їх, оскільки він вклав у них власні гроші і забороняє авторам розповсюджувати отримані знання.

Що ж у такій ситуації робити вченому? Знову або мовчати про свої дослідження, або говорити про них так, щоб не сказати нічого зайвого. Сказати про свої дослідження так, що промовчати про певні нюанси, незнання яких не дозволить відтворити експеримент іншим дослідникам в інших лабораторіях, бо хтось зможе скоріше або запатентувати, або презентувати широкому загалові, або виграти грант, або отримати ще якісь переваги. На жаль, у сучасній науці перед ученим стоїть важкий вибір: працювати на своє ім'я або працювати на замовника заради отримання певних статків.
Під впливом суспільних змін відбулися певні зміни в науці, що змінило систему ціннісних орієнтацій більшості вчених. Те, що було неприпустимим для вчених XIX-XX століть, як-от замовчування результатів досліджень або подання в такій формі, щоб їх не можна було відтворити, стало буденністю для більшості вчених XXI століття. Страх не встигнути за стрімким розвитком науки, відстати від її передового краю (навіть на деякий час, навіть через поважну причину, як-от хвороба, сімейні обставини тощо), виявлятися «несучасним», не зовсім обізнаним у нових знаннях, технологіях, методиках, не зовсім цікавим для молодих учених та вчених світового рівня, який бентежив уми відомих учених ХХ століття, перестає бути чимось значущим для більшості вчених XXI століття, адже їм достатньо бути обізнаними у вузький галузі прикладних досліджень. Усе частіше перед науковцями стоїть вибір: залишитися у фундаментальній науці і працювати на своє ім'я чи перейти до прикладної науки, тобто продати свої майбутні відкриття, не заробити собі ім'я, однак забезпечити себе і свою родину. А оскільки в системі ціннісних орієнтацій людини родина і родинне щастя перебувають на першому місті, то все частіше вибір робиться на користь забезпечення власної родини.

Висновки. Отже, зміни, які відбуваються в суспільстві, неодмінно приводять до змін у науці, а це відбивається на зміні ціннісних орієнтацій вченого, на його ставленні до роботи, настрою, емоційному стані. А тому уявляти науку як щось об’єктивне, незалежне від суб'єктів, учених, на нашу думку, є дуже спрощеною, примітивною точкою зору. Слід визнати, що суб'єктивний фактор і аксіологічний складник не можна виключити ані з науки загалом, ані з будь-якого дослідження, ані з процедури вимірювання зокрема. Тому іншою цікавою темою є аналіз ціннісних орієнтацій особистості, того, як вони формуються і змінюються протягом життя. Окрему зацікавленість викликає можливість безеталонного вимірювання процедури формування і змін ціннісних орієнтацій, які відбуваються протягом життя.

\section{Jimepamypa}

1. Lindsay R.B. The future of theoretical physics. Phil. of Science, 5, 1938. $343 \mathrm{p}$.

2. Берка К. Измерения. Понятия, теория, проблемы. Москва : Прогресс, 1987. 320 с.

3. Готинян-Журавльова В.В. Соціально-філософські складові безеталонного вимірювання: види, визначення, застосування : монографія. Одеса : Видавничий дім «Гельветика», 2020. 358 с.

4. Пружинин Б.И. Культурно-историческая эпистемология: концептуальные возможности и методологические перспективы. Вопросы философии. 2014. № 12 . C. 3-14.

5. Agassi J. Science and Society. Boston Studies in the Philosophy of Science. Boston, Dordrent : Reidel, 1981. Vol. 65. pp. 104-118. 


\section{Анотація}

Готинян-Журавльова В. В. Вплив соціокультурних змін у суспільстві на систему ціннісних орієнтацій ученого. - Стаття.

У статті розглядається вплив змін, які відбуваються в суспільстві, на зміну пріоритетів сучасної науки та систему ціннісних орієнтацій і роботу вченого. Зміни, які останнім часом відбулися в суспільстві, не могли не відбитися на роботі вченого. Так, за останні сто років науковці почали займатися прикладними дослідженнями. Фундаментальна наука відійшла на другий план. Більшість прикладних досліджень мають замовників, спонсорів, які фінансують ці проєкти і мають певні права на результати досліджень. А замовник не вважає за необхідне ділитися результатами досліджень, оскільки вони є його власністю та засобом для дослідження іншої мети. Сучасній науці властива ситуація, коли вчені перестають ділитися результатами власних досліджень, оскільки вони їм не належать. Статті пишуться так, щоб «сказати» якомога менше, надати неповну інформацію, яку не можна було б повторити в інших лабораторіях, іншими вченими. Гонитва за грантами, грошовими винагородами, робота на замовника надає певну фінансову стабільність ученому, але при цьому він втрачає можливість вільного спілкування, обміну інформацією і розповсюдження результатів власних досліджень. Така ситуація була неприпустимою для вчених XIX та XX століть. Таким чином, зміни, які відбуваються в суспільстві, неодмінно приводять до змін у науці, що відбивається на зміні ціннісних орієнтацій ученого, на його ставленні до роботи, настрою, емоційному стані. Перед ученим постає вибір: працювати в межах фундаментальної науки i вільно розпоряджатися результатами досліджень або працювати на замовника, отримуючи значно більший дохід, але обмежуючи власну можливість розпоряджатися результатами досліджень. А тому уявляти науку як щось об'єктивне, незалежне від суб'єктів, учених, на нашу думку, є дуже спрощеною, примітивною точкою зору.

Ключові слова: вимірювання, безеталонне вимірювання, ціннісні орієнтації вченого, фундаментальна наука, прикладна наука, замовник.

\section{Summary}

Gotynyan-Zhuravlyova $\quad$. $\quad V$. Influence of sociocultural changes in society on the system of value orientations of the scientist. - Article.

The article discusses the impact of changes taking place in society, the change of priorities of modern science and the system of value orientations and the work of the scientist. The changes that have recently taken place in society could not but affect the work of the scientist. Therefore, over the past hundred years, scientists have begun to engage mainly in applied research. Fundamental science has come to the fore. The vast majority of applied research has customers, sponsors who finance these projects and have certain rights to research results. Moreover, the customer does not consider it necessary to share the results of research, since they are his property and a means to study another purpose. Modern science is characterized by a situation when scientists stop sharing the results of their own research, because, in fact, they will not give them. Articles are written in such a way as to "say" as little as possible, to provide incomplete information that could not be repeated in other laboratories by other scientists. The pursuit of grants, monetary rewards, work for the customer, provides a certain financial stability to the scientist, but at the same time he loses the opportunity to freely communicate, exchange information and disseminate the results of his own research. This situation was unacceptable for scientists of the 19th and 20th centuries. Thus, the changes that occur in society certainly lead to changes in science, and this is reflected in the change in the value orientations of the scientist, in particular, in his attitude to work, mood, emotional state. Scientists face a choice: to work within the fundamental science and freely dispose of the results of research or work for the customer, receiving a much higher income, but limiting their own ability to dispose of the results of research. Therefore, to imagine science something objective, independent of subjects, scientists, in our opinion, is a very simplified, primitive point of view on the real state of affairs.

Key words: measurement, standardless measurement, value orientations of the scientist, fundamental science, applied science, customer. 